\title{
Operationalizing payments for ecosystem services in Brazil's sugarcane belt: How do stakeholder opinions match with successful cases in Latin America?
}

\author{
Rafaela A. Silva ${ }^{a}$, David M. Lapola ${ }^{\mathrm{b}, *}$, Gleiciani B. Patricio ${ }^{\mathrm{b}}$, Moara C. Teixeira ${ }^{\mathrm{a}, \mathrm{b}}$, Patricia Pinho ${ }^{\mathrm{c}}$, \\ Joerg A. Priess ${ }^{\mathrm{b}, \mathrm{d}}$ \\ a Programa de Pós-graduação em Ecologia e Biodiversidade - Instituto de Biociências, Universidade Estadual Paulista - UNESP, Brazil \\ ${ }^{\mathrm{b}}$ Laboratório de Ciência do Sistema Terrestre, Departamento de Ecologia, Universidade Estadual Paulista - UNESP, Avenida 24-A, 1515, CEP: 13506-900 \\ Rio Claro, SP, Brazil \\ ${ }^{\mathrm{c}}$ INCLINE, Instituto de Astronomia e Geofísica, Universidade de São Paulo - USP, São Paulo, SP, Brazil \\ d Department Computational Landscape Ecology, Helmholtz Centre for Environmental Research - UFZ, Leipzig, Germany
}

\section{A R T I C L E I N F O}

\section{Keywords:}

Atlantic Forest

Brazilian Forest Code

Nature conservation

Public policies

Rio Claro - SP municipality

Participatory methods

\begin{abstract}
A B S T R A C T
In this paper the initial draft design of a payment for ecosystem services (PES) scheme in a municipality within the sugarcane belt of São Paulo state, Brazil (PES-RC), is compared with prevailing characteristics of successful PES cases in Latin America (PES-LA). This systematic comparison is performed by analyzing four major characteristics of PES: identity of traded ecosystem service (ES); spatial scale; type of transaction involved between ES providers and beneficiaries; and the involved actors. Information on the biophysical characteristics, institutional arrangement and financial options of PES-RC were assessed using participatory methods. We found that on the one hand there is an agreement between our case study and the prevailing successful cases of PES-LA regarding the traded ES (water) and the PES spatial scale (local). However, stakeholder opinions diverge from the success cases when it comes to the type of transaction (cash preferred in PES-RC; in-kind in successful PES-LA) and the involved actors. Our results raise the question whether stakeholder opinions or the characteristics of successful (or failure) cases should be prioritized when planning and operationalizing new PES schemes. We argue that stakeholder participation should be considered as an additional success criterion for the construction of public policies directed towards PES implementation.
\end{abstract}

\section{Introduction}

The Brazilian Forest Code (FC) is the main law regulating land use and management in the country's farms since 1934 (Brasil, 2012; Soares-Filho et al., 2014). It requires landowners to protect native vegetation inside their properties through a Legal Reserve (LR; $80 \%$ of farm area in the Amazon and 20\% in other biomes) and also through Areas of Permanent Preservation (APPs; forest alongside water bodies, hilltops and steep slopes). It was originally intended to "punish" noncompliant farmers by not granting them access to agricultural credits. Even though the law has been reviewed during the last decades, it has historically failed in its key-objective of conciliating agricultural production with conservation of natural resources, because both the compliance with and the enforcement of this law over the years have been low (Soares-Filho et al., 2014). As a result, there is a considerably high deficit of natural vegetation in relation to what is requested by the FC, especially in the Amazon deforestation frontier areas and throughout the Atlantic Forest biome. This latter region is where large extents of sugarcane plantations, as well as pasturelands for cattle ranching and most of the country's population are located (Lapola et al., 2014) [see Supplementary material Section 1].

The new version of the FC issued in 2012 includes, for the first time in the history of this law, the possibility of payments or incentives for the conservation or restoration of ecosystem services (ES) such as carbon storage, conservation of biodiversity, water resources, soil properties, the fostering of cultural services and traditional knowledge, or simply the conservation of natural vegetation areas (Brasil, 2012). This represents a major step in the way LRs and APPs are seen in the

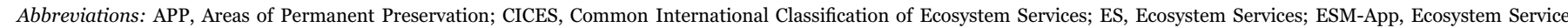

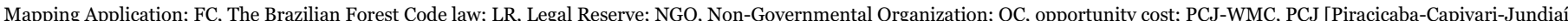

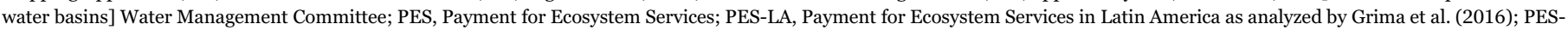
RC, Framework of Payment for Ecosystem Services in Rio Claro - SP municipality, Brazil

* Corresponding author.

E-mail address: dmlapola@rc.unesp.br (D.M. Lapola). 
context of agricultural production, shifting from a paradigm of surveillance and fines for non-complying farmers to a paradigm of incentives for complying farmers. As such, PES schemes arise as a promising choice for landowners to comply with the FC (Grima et al., 2016; Pagiola et al., 2012).

However, the law does not specify the mechanisms through which ES could be identified, quantified and valued, neither how the PES schemes could nor should be organized in institutional and financial terms. So far, PES schemes in Latin America (PES-LA) are mostly implemented at the local scale [Supplementary material Section 2].

As such, it is reasonable to assume that one has to rely on the experience provided by successful cases of PES - regardless of their planning process - in order to increase the likelihood of success of new schemes under planning or implementation. On the other hand, the strong involvement of stakeholders in the planning, implementation and execution phases of a PES scheme is also increasingly seen as decisive for success (Alcamo et al., 2005; Grima et al., 2016; Henrichs et al., 2010; Priess and Hauck, 2014; Wegner, 2016). In this paper these two relevant and potentially antagonistic issues related to PES are confronted with the planning steps taken for developing a PES scheme in the municipality of Rio Claro (PES-RC) within the sugarcane belt of the state of São Paulo, Brazil. We compare them in a systematic fashion to the main characteristics of successful PES-LA as shown by Grima et al. (2016).

We explore the biophysical, institutional and financial options (which cover the major aspects of PES planning), to assess how they may influence the operationalization of PES-RC, applying participatory methods involving key stakeholders in the project either as ES providers, intermediaries or beneficiaries. As such, we assess:

- The portfolio of ES potentially supplied in the study region, via mapping ES related to the key land use types of the region;

- Stakeholder perceptions on ES and PES via different methods including a public survey, workshops and interviews;

- The link between stakeholder perceptions and the relevant legal frameworks, and, based on the previous items, defining the options for establishing the PES-RC scheme.

Finally, we systematically compare and discuss the characteristics that are shaping the PES-RC scheme under operationalization, with the overall characteristics of successful PES-LA.

\section{Materials and methods}

The methods used to pursue this paper's objectives were applied in two steps:

1. Acquisition of biophysical and socio-economic information about PES-RC planned in the study area. We collected information and assessed the opinions/perceptions about ES/PES from both potential ES providers and beneficiaries and also from intermediaries ${ }^{1}$ such as governmental institutions who could have a role in the institutional, political, financial or technical aspects of PES-RC. The following approaches were developed concomitantly (Fig. 1): mapping of used ES in the study area; individual interviews with farmers; meetings with decision makers; public opinion survey; and workshops with stakeholders. The selection of stakeholders to participate in the workshops and interviews with farmers was based on a non-probabilistic sampling, or so-called convenience sampling (Ritchie et al., 2014). Despite the consideration that this strategy may induce a systematic bias in the assessed opinions, it is most

\footnotetext{
${ }^{1}$ Intermediaries are defined here as any institution to which both ES providers and beneficiaries will report and communicate with, implying that there is no direct contact, negotiation and/or reporting between providers and beneficiaries.
}

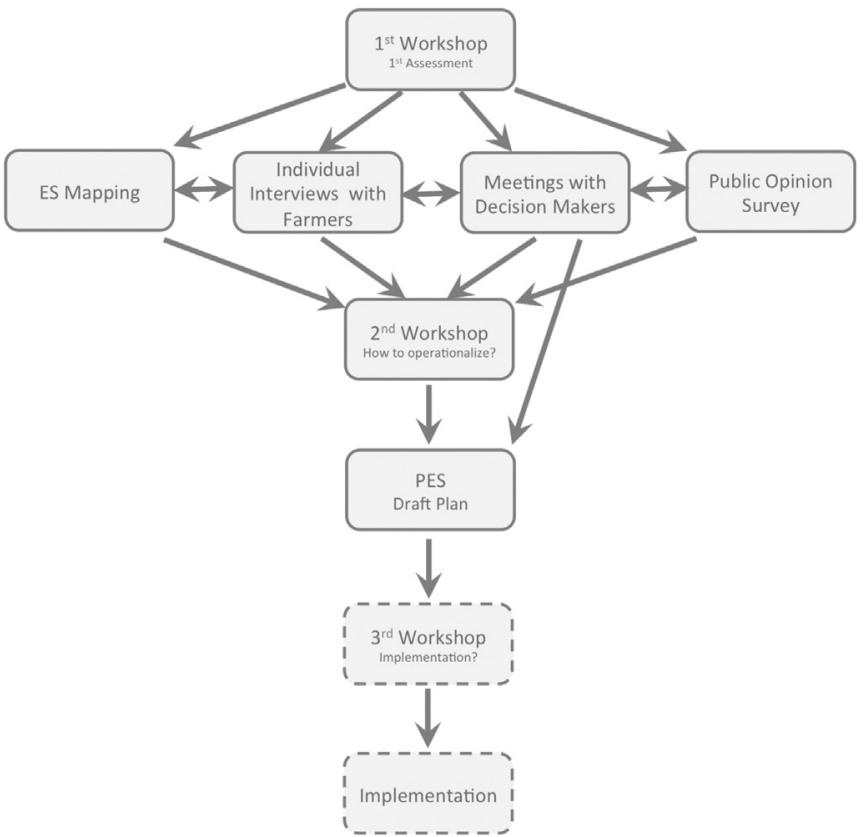

Fig. 1. Overview of the methods employed in this study for the acquisition of biophysical and socio-economic information and planning of the PES Scheme to be implemented in Rio Claro - SP municipality, shown in the order of execution (from top to bottom): the 1st workshop aimed at an initial assessment of farmers' and, to a smaller extent, decision makers' knowledge and perceptions about ES/PES; the mapping of ES aimed at identifying the current use of ES in Rio Claro municipality; individual interviews with farmers, meetings with decision makers and the public opinion survey targeted the assessment of detailed opinions from ES providers, intermediaries and beneficiaries; the 2nd workshop focused on the presentation of first results to decision-makers, and the discussion of regulations for a PES-RC and how to translate these opinions into a public policy; next step then was the elaboration of a draft plan for PES-RC by the scientists and decision makers, considering the opinions gathered in the 2nd workshop; next steps, are the 3rd workshop which will tackle the technicalities for implementing PES-RC and the implementation itself by the municipality government (dashed boxes, not addressed in this paper).

probably the only viable method to develop a participatory outline of a potential PES-RC, given that opinion surveys depend strongly on people's willingness to participate (Peterson and Merunka, 2014). The assessment of the current use of ES was based on a participatory mapping approach, which is presented below (see Sections 2.2-2.5).

2. Systematic comparison of the foundational characteristics of PES-RC gathered at " 1 " with the characteristics of successful PES-LA as presented by Grima et al. (2016). The aim here was to assess whether PES-RC was on the right track to a successful PES framework within the Latin American context. By "success" we mean that the PES scheme accomplishes its goals and attains some additionality (in environmental, social and/or economic terms) that would not be reached without the scheme (see Section 2.6).

\subsection{Study region: Rio Claro - SP municipality}

Rio Claro municipality is located in the centre-east part of the state of São Paulo and is considered a mid-sized town with approximately 200,000 inhabitants - with 97,6\% living in the urban areas (IBGE, 2014). It is a typical municipality within São Paulo's sugarcane belt (in geographic and socio-economic terms), having sugarcane plantation widespread in its flat areas and pastures predominantly in the hilly areas (Fig. 2). Compared to other regions in Brazil, the study region is intensively managed, with high agricultural productivity and intense pressure on land resources, leading to the current $66 \%$ deficit in natural vegetation according to the FC (Soares-Filho et al., 2014), which caused the decrease of many important ES associated with 

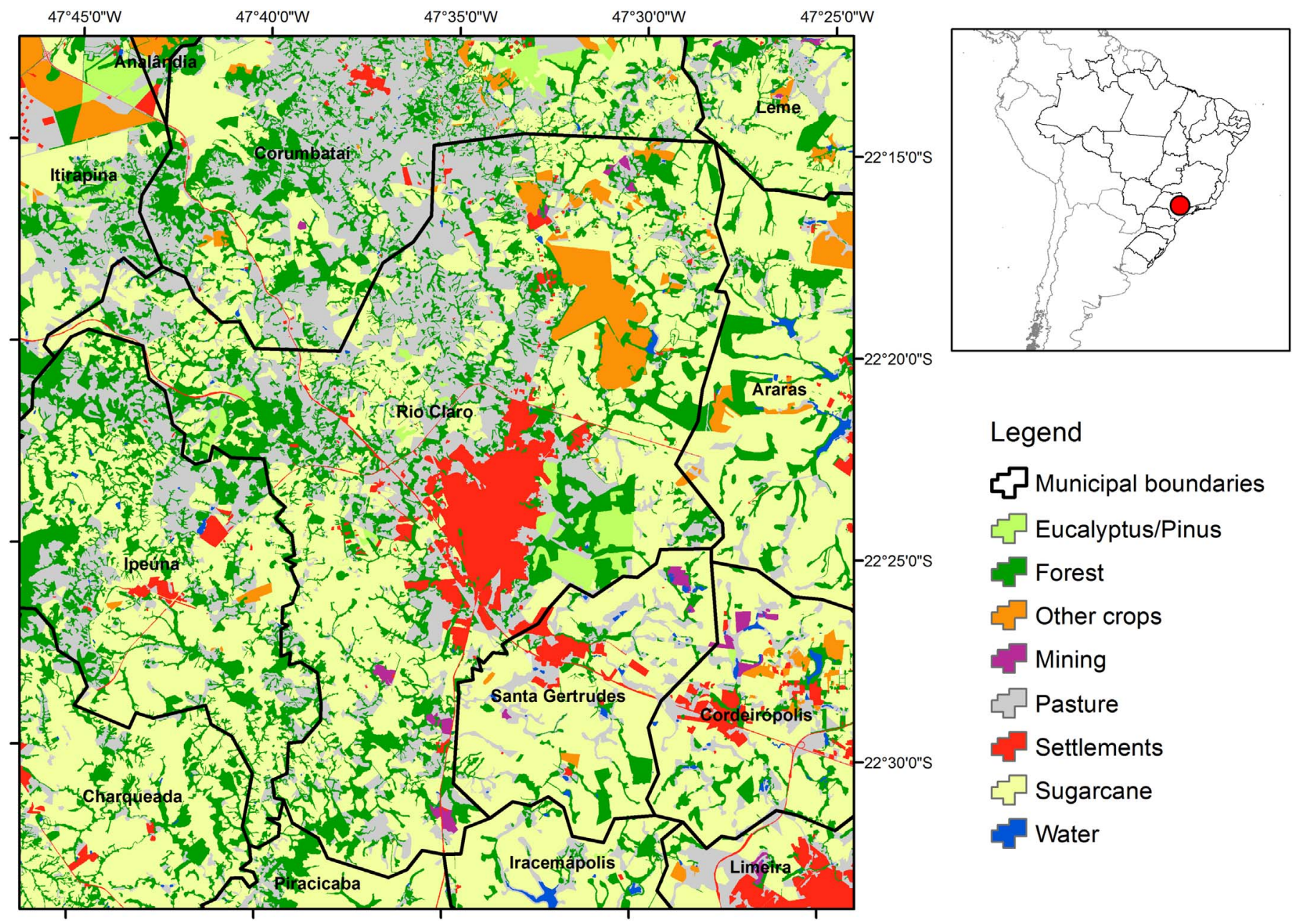

Legend

Municipal boundaries

Eucalyptus/Pinus

Forest

Other crops

Mining

5 Pasture

Settlements

ᄃ Sugarcane

Water

Fig. 2. Land use in Rio Claro and surrounding municipalities, State of São Paulo, Brazil.

natural vegetation (Phalan et al., 2011). Thus, it offers excellent opportunities for the establishment of a PES scheme or comparable approaches to shift the balance between agriculture and natural vegetation, safeguarding and restoring natural resources and the ES derived from them (Grima et al., 2016; Pagiola et al., 2012). See also Supplementary material for further information on the study region.

\subsection{Elicitation workshops}

Two elicitation workshops were conducted (see Fig. 1). The first was held with the aim of gathering first order impressions of farmers and decision-makers about their perception on ES and possible PES schemes, discussing valuation methods, and institutional and financial options. The second workshop focused on assessing the opinions from decision-makers (namely from the City Hall, City Council and the PCJ [Piracicaba-Capivari-Jundiaí water basins] Water Management Committee, PCJ-WMC) about the technical aspects of governance, funding and potential standards for a PES scheme in Rio Claro. For this workshop farmers were initially contacted through the city's rural labor union. The workshop was also advertised in the City Hall, City Council and PCJ-WMC. Decision-makers as well as farmers were invited via formal invitation letters. Both workshops were also a means to start the science-policy-stakeholder dialogue with different groups and to discuss relevant prospects for a PES-RC operationalization.

Workshop 1: 30 stakeholders participated in this workshop. First, the basic concepts of ES, PES and their relation to the new FC were presented by the scientists leading the project. Second, a member of an NGO involved in the PES scheme in Extrema-MG (Cassola, 2010) shared his experience. Subsequently, two city council members explained legal and financial mechanisms for implementing a PES-RC. Finally, the researchers organized a group-activity with the intention of farmers discussing and sharing their knowledge on the identification, quantification and valuation of ES on their farms and to brainstorm about possible financial resources for a regional PES and the main obstacles expected. The four groups presented their results, which were debated in a final discussion.

Workshop 2: 39 people attended the workshop including the vicemayor, city-secretaries for agriculture and for the environment, citycouncilors, members of the PCJ-WMC, scientists and farmers. This workshop focused on the advances in the discussions of PES operationalization. The workshop started with a presentation by the vicemayor about the municipal environmental analysis, followed by a presentation of the scientific project, which this study is part of. Afterwards the attendees were requested to discuss and answer a set of eight questions (see Supplementary material), such as which ES should be in the focus of a PES scheme, whether the scheme should aim at the entire farm- or only at the forest areas, the most appropriate and convenient method to compensate farmers (from the perspective of the attendees), and which institution should manage the scheme and the transactions.

\subsection{Ecosystem services mapping}

Data collection was carried out in two steps. First, we employed MapNat the Ecosystem Service Mapping Application for Android smartphones (Priess et al., 2014; beta version publicly available at 
http://www.ufz.de/index.php?en=40618) at 15 farms, mostly dominated by sugarcane production, mapping partly with and partly without farmers. Other agricultural activities on these farms included cattle ranching and the production of vegetables and fruits. The ESMApp relies on an adapted version of the list of Common International Classification of Ecosystem Services - CICES (Haines-Young and Potschin, 2013) and uses smartphones with GPS functionality to locate ES, which are identified by the App user in the field. Second, we included information about ES provided by farmers during interviews and other meetings, e.g. about the use of their land by cross-country bikers or leisure fishermen. The ES map was developed based on the sources presented above, linking ES and land use, a common approach to provide a first order overview of ES supply or use (Crossman et al., 2013; Maes et al., 2013). We used a recent land use map adapted from Vedovato (2013) and ArcGIS to develop an ES map of the study region, inferring the occurrence of ES based on the field data collected with MapNat and the farmer interviews.

\subsection{Meetings with decision makers}

These meetings with decision makers were conducted with the purpose of investigating (i) the municipality's level of interest in implementing a PES-policy, (ii) the existing legal means to do so, (iii) how transactions for ES suppliers could be organized, and (iv) the potential sources of funding. During the meetings, we presented results from other activities related to this study (interviews, workshops, ES mapping) and discussed them in the perspective of a municipal PES scheme. One of these meetings had the participation of two city counselors and, and in three other the participation of the city mayor and/or the vice-mayor, and representatives of the city Secretariats of Agriculture and of the Environment.

We also joined official meetings of the PCJ-WMC, an important regional institution managing the water of the three largest region's rivers, as well as the funds collected from the use of the water resources (the majority of which, $42 \%$ is used to attend urban demand, 35\% for industrial purposes and $22 \%$ for farming). The PCJ-WMC has already contributed financially to other PES schemes in the region.

Our goals during these meetings were (i) to understand the operationalization of PES pilots in other municipalities and (ii) to investigate the possibility to raise funds or any form of compensation that PCJ-WMC could contribute to the implementation of PES-RC.

\subsection{Public opinion survey}

Given that many ES provided in the region originate from private properties to which the public mostly does not have access, we paid special attention to ES with expected diffuse beneficiaries, i.e. ES whose group of beneficiaries cannot be precisely delimited, such as the maintenance of water resources or carbon storage. In order to assess the perceptions on ES and PES from diffuse beneficiaries, we contracted a company to carry out a public opinion survey in Rio Claro municipality. The company interviewed 400 heads of households ( $>16$ years old; $46 \%$ male; $54 \%$ female). This is a representative share of Rio Claro population according to the Probability Proportional to Size method (Cochran, 1997). Interviewees belonged to neighborhoods with different socioeconomic and literacy levels, classified in six groups, according the Paulista Social Vulnerability Index. Group one represents the social class with the least social vulnerability (i.e. with higher income) and group six represents the social class with the highest social vulnerability. The questionnaire comprised 45 questions originally elaborated in Portuguese - an English version is shown in the Supplementary material. They ranged from open questions inquiring the interest in environmental issues, to very specific questions on ES/PES such as opinions about whether participants would accept to pay an additional tax in their water bill to support a PES-RC. The questionnaire and the full survey results are available upon request from the authors.

\subsection{Comparison between PES-RC and successful PES-LA}

The comparison of the characteristics of the planned new PES-RC and the successful cases of PES-LA was carried out based on the review by Grima et al. (2016). Following their evaluation, we used four criteria to determine how similar or different PES-RC is from the successful cases of PES-LA. These criteria are:

(1) ES under trade - biodiversity conservation, protection of landscape of scenic value for tourism; protection and improvement of water resources; building up and/or maintaining carbon stocks; or "bundled" services (multiple ES provided together).

(2) Spatial scale - whether the PES scheme aims at national, regional or local scale. Given that PES-RC has not defined a temporal scale yet, we could not include this aspect in the comparison.

(3) Type of transaction - if the PES scheme involved cash, in-kind or both transactions between ES providers and beneficiaries. In-kind transactions represent the delivery of goods and services to providers without payments being involved.

(4) Involvement of actors - whether ES buyers (beneficiaries) are public, private or both; if ES providers are public or private; and whether intermediaries between providers and beneficiaries are involved.

\section{Results}

\subsection{Ecosystem service mapping}

We identified 23 ES being used on nine different land use types. Six of the ES were classified as provisioning, ten as regulating and seven as cultural according to CICES (Table 1). Land cover/use category 'forest' was the one with the largest number (14) of ES identified by farmers alongside with scientists (Fig. 3). Six of the identified ES were related to water resources; sugarcane plantations were associated with four ES, and only one ES was found in pastures (Table 1). Additionally, farmers reported that almost the entire rural area is used for cross-cycling, mostly during weekends. One should notice that the list of potential supply of ES in the region may be considerably larger than the list of observed and reported use of ES presented here (given that there is a difference between ES supply and usage).

Almost all of the ES associated with forests were classified as regulating services, only one as provisioning (fiber and other material from plants) and three as cultural (barbecuing, biking and aesthetic). Given that most of the forests remnants were associated with water bodies, water-related services were attributed to the land use type forest (Figs. 1 and 3). Spatially, the ES associated with sugarcane and cattle ranching are dominating in the region.

\subsection{Elicitation workshops}

The results from all focal groups in the 1st workshop were convergent concerning the ES identified on their property and their value in maintaining agricultural productivity. Farmers identified ESrelated attributes on their farms such as water conservation, natural vegetation, soil conservation practices as well as biodiversity and carbon stocks (these services reported by farmers were also included in the ES mapping presented above). They also noticed the necessity of strong investments in restoration projects, as they were aware of degradation processes in the landscape surrounding them.

There was a common understanding among farmers that a PES scheme to protect ES should be based on the opportunity cost (OC) method (Seroa da Motta, 1997), with the vast majority preferring payments in cash. Stakeholders also agreed that the government (at the federal, state or municipality level) should promote fiscal incentives to foster ES protection increasing benefits for society as a whole. They argued that industries should pay for environmental degradation and natural resource use. Participants also suggested an extra fee in the 
Table 1

List of reported ES use in the Rio Claro - SP region, Brazil.

\begin{tabular}{|c|c|c|c|c|c|c|c|c|c|c|}
\hline \multirow[t]{2}{*}{ Ecosystem Services } & \multicolumn{10}{|c|}{ Vegetation/ Land Use } \\
\hline & $\begin{array}{l}\text { Sugarcane } \\
\text { fields }\end{array}$ & $\begin{array}{l}\text { Other } \\
\text { crops }\end{array}$ & Pasture & River & Springhead & $\begin{array}{l}\text { Lake (natural } \\
\text { and artificial) }\end{array}$ & $\begin{array}{l}\text { Eucalyptus } \\
\text { plantation }\end{array}$ & Forest & Settlements & Total \\
\hline \multicolumn{11}{|l|}{ Provisioning services } \\
\hline $\begin{array}{l}\text { Cultivated Crops (food and } \\
\text { feed) }\end{array}$ & 1 & 1 & & & & & & & & 2 \\
\hline Biomass for energy & 1 & & & & & & & & & 1 \\
\hline $\begin{array}{l}\text { Reared animals (meat and } \\
\text { milk) }\end{array}$ & & & 1 & & & & & & & 1 \\
\hline Surface water for drinking & & & & 1 & 1 & & & & & 2 \\
\hline $\begin{array}{l}\text { Surface water for non- } \\
\text { drinking purposes }\end{array}$ & & & & 1 & & 1 & & & & 2 \\
\hline $\begin{array}{l}\text { Fibers and other material } \\
\text { from plants }\end{array}$ & & & & & & & 1 & 1 & & 2 \\
\hline \multicolumn{11}{|l|}{ Regulating services } \\
\hline $\begin{array}{l}\text { Mass stabilization and control } \\
\text { of erosion rates }\end{array}$ & & & & & & & & 1 & & 1 \\
\hline $\begin{array}{l}\text { Buffering and attenuation of } \\
\text { mass flows }\end{array}$ & & & & & & & & 1 & & 1 \\
\hline $\begin{array}{l}\text { Hydrological cycle and water } \\
\text { flow maintenance }\end{array}$ & & & & & & & & 1 & & 1 \\
\hline Pollination and seed dispersal & & & & & & & & 1 & & 1 \\
\hline $\begin{array}{l}\text { Maintaining nursery } \\
\text { populations and habitats }\end{array}$ & & & & & & & & 1 & & 1 \\
\hline $\begin{array}{l}\text { Decomposition and fixing } \\
\text { processes }\end{array}$ & & & & & & & & 1 & & 1 \\
\hline Weathering processes & & & & & & & & 1 & & 1 \\
\hline $\begin{array}{l}\text { Chemical condition of } \\
\text { freshwaters }\end{array}$ & & & & & & & & 1 & & 1 \\
\hline $\begin{array}{l}\text { Micro and regional climate } \\
\text { regulation }\end{array}$ & & & & & & & 1 & 1 & & 2 \\
\hline Global climate regulation & & & & & & & 1 & 1 & & 2 \\
\hline \multicolumn{11}{|l|}{ Cultural services } \\
\hline Barbecuing and picnicking & & & & & & & & 1 & & 1 \\
\hline Scientific & & 1 & & 1 & & & & & & 2 \\
\hline Educational & & 1 & & 1 & & & & & 1 & 3 \\
\hline Cultural Heritage & & & & & & & & & 1 & 1 \\
\hline Aesthetic & & & & 1 & 1 & 1 & & 1 & & 4 \\
\hline Biking & 1 & 1 & 1 & & & & 1 & 1 & 1 & 6 \\
\hline Fishing & & & & 1 & & 1 & & & & 2 \\
\hline Total & 3 & 4 & 2 & 6 & 2 & 3 & 4 & 14 & 3 & 41 \\
\hline
\end{tabular}

water bill (further explored in the public opinion survey) as another option to raise funds for ES protection on private land.

We attempted to gather farmers' knowledge and perceptions about major threats to ES on their farms and the potential obstacles to advancing a PES scheme. They mentioned several threats such as population growth, arson in the landscape, exotic species and soil erosion (in the order of farmers' priorities). When asked what they thought were the major impediments or difficulties, in general, to the implementation of a PES scheme in the study area they mentioned (in order of frequency of answers): the absence of technical assistance (from people/companies specialized in forest restoration/conservation), financial resources (for funding in-cash payments to farmers) and incentives from governmental bodies (in terms of bridging ES providers and users) also hinder the maintenance of ES and the implementation of PES. There was a consensus among farmers that society in general does not recognize the benefits arising from rural landscapes, a consequence of the strong level of urbanization of the region's population, and of the low local economic importance of agriculture which responds for only $0.5 \%$ of the municipality GDP: this may be crucial in driving a lack of trust and detachment/estrangement in general between farmers and the urban population. ${ }^{2}$ Farmers also

\footnotetext{
${ }^{2}$ To such a level that there is currently a propaganda campaign now in one of the main Brazilian TV channels trying to bring about the benefits of agriculture and agro-industry to the population.
}

regretted the lack of a farmers' union. Finally, the farmers suggested that partnerships and alliances between themselves, the government, and the industry, as well as assistance of the scientific community, could transform the valuation of the rural environment towards ES maintenance and protection for the benefit of society.

Participants of the 2nd workshop suggested to implement a "pilot PES" first in the municipality areas most urgently in need of forest restoration. The North/Northwest part of the municipality where many water wells are located, was considered a priority area to implement the pilot. There was no consensus among participants whether the PES scheme should aim at water-related ES occurring on the entire farm area, or only on the farm forests. Even those in favor of an "entire farm" approach argued that certain soil conservation practices used in croplands can have a significant impact on the conservation of water resources. Therefore, despite the disagreement among farmers about the extent and types of land cover to be considered in PES-RC, the majority of them were aligned when it came to the ES that should be privileged, namely the conservation of water resources. Furthermore, no consensus was achieved yet on the question whether different levels of payment or compensation should apply for farmers to conserve their forests and those who need to restore their forests (i.e. those who are not in compliance with the FC). Participants also highlighted the importance of governance structures for such a scheme, especially the executing body that could act as an intermediary between ES providers and beneficiaries. The institution was expected to have a trustworthy relation with farmers - the two most mentioned options 

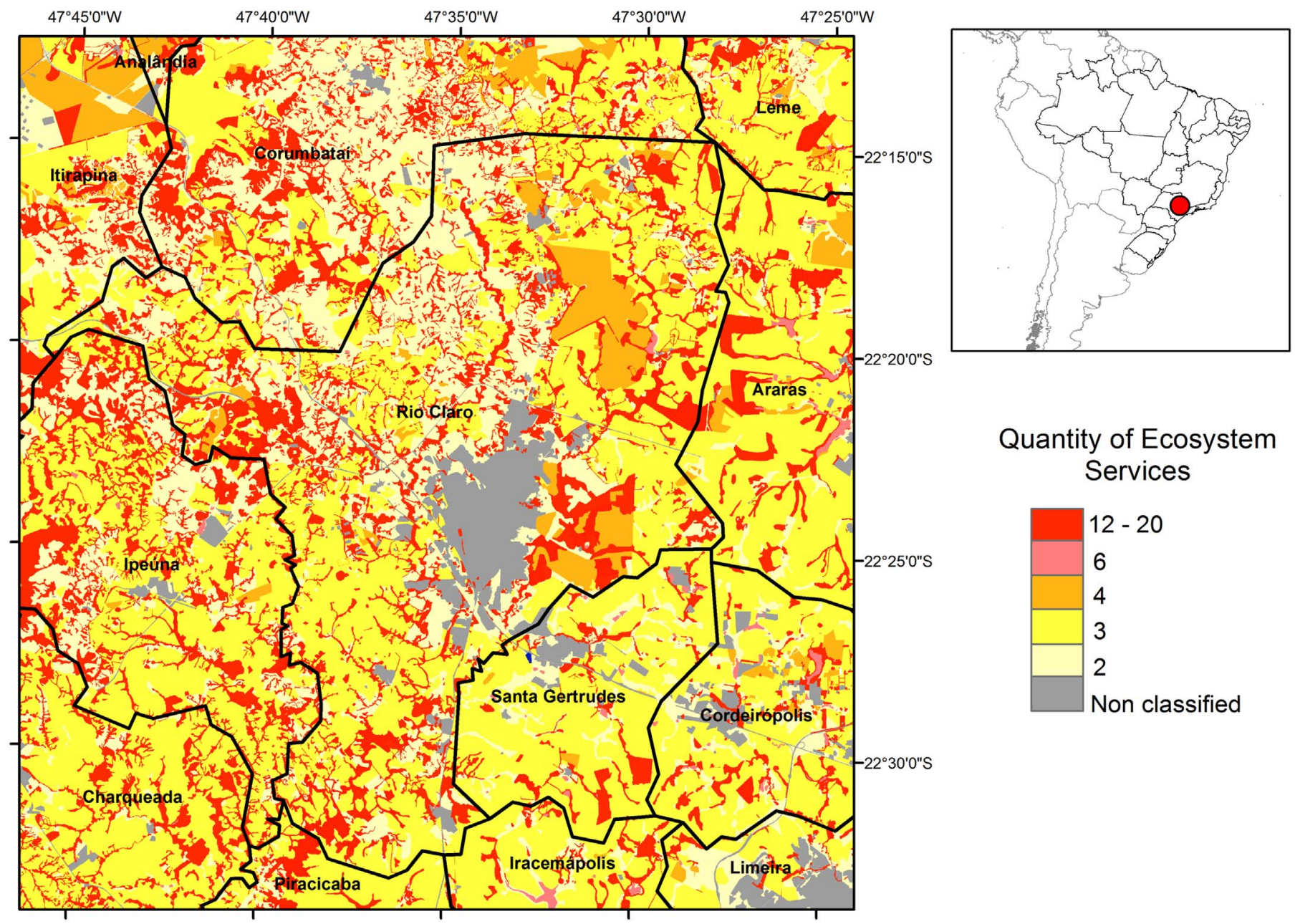

\section{Quantity of Ecosystem Services}

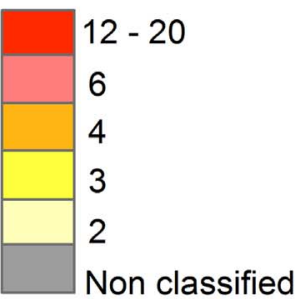

Fig. 3. Map of reported ES use in the Rio Claro - SP region, Brazil.

were the city Secretariat of the Environment and the city autonomous department for water supply. Although OC was again the preferred method for the compensation of farmers, participants agreed that other alternatives could be considered, including non-monetary options. Such a payment, according to participants, should cover the area of forest (or entire farm) as the basis of calculation for the due payment, but without counting the amount of water or number of wells comprised in that area of forest or farm. Consequently, beneficiaries would not all receive the same sum, but in principle, payments would be based on area and not on the number of wells protected nor the amount of water delivered.

\subsection{Meetings with decision makers}

Our meetings with decisions makers showed that the mayor and his staff are supportive of the implementation and regulation of PES schemes. However, financing of compensations was, and still is the main obstacle. They argued that the municipal budget was already committed to other policies, and that they currently see no alternative possibility for investments in new initiatives.

The city of Rio Claro does not yet have effective laws or regulations addressing environmental policies for the municipality or any municipal funds for the environment that could be dedicated to PES. However, the municipality government is willing to discuss the implementation of a PES scheme and to find solutions for the current lack of monetary resources. Amongst the options listed by them were (in the order considered relevant and feasible):
- The Municipal Fund for the Environment, which would designate funds from either the municipal budget or new taxes/fees to a PES.

- Direct funding by the population (see next section).

- Partnerships with State and/or Federal Government bodies, the PCJ-WMC, or the private sector. However, the PCJ-WMC informed that due to legal restrictions, their resources can be applied only to fund the administration of a PES.

- Voluntary private initiatives e.g. by associations or companies. Although they are considered important potential PES partners and sources of funding and other contributions such as technical assistance, a considerable risk is foreseen that companies may constrain or cease their contributions in times such as the current economic crises.

Despite the elucidation of the theme and the majority of decision makers supporting the PES ( 7 out of 8 contacted), one city councilor was skeptical about a potential PES scheme and disagreed with the envisaged viability of its implementation. This city councilor expressed concerns about the financial viability of the program over time and the commitment of society to collaborate with financial contributions, even if it would be established by a law or other public policies.

As a conclusion, the meetings showed that most decision makers are interested in a PES that aims to incorporate mainly water-related ES. It was a topic of interest and concern since the results of the Environmental Diagnosis (Rio Claro, 2014), pointed at the possibility of water scarcity in the near future, because water resources are expected to continue degrading rapidly, if no interventions are planned. In any case the consulted decision-makers argue that the 


\section{a}

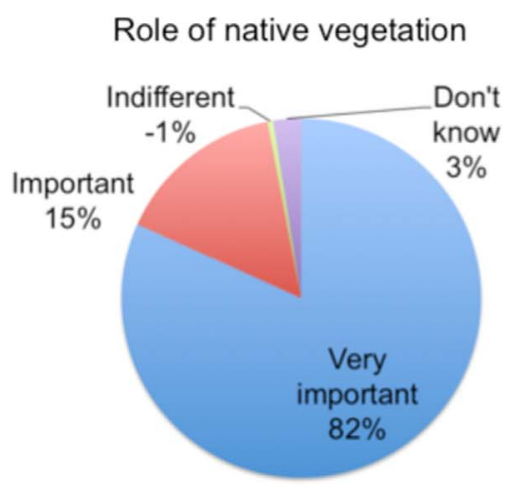

d

\section{Farmers should be financially helped?}

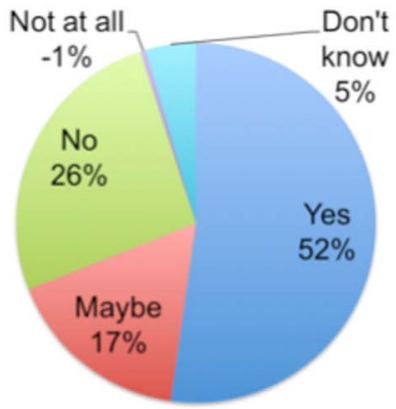

b

\section{How forest restoration could change the quality of life?}

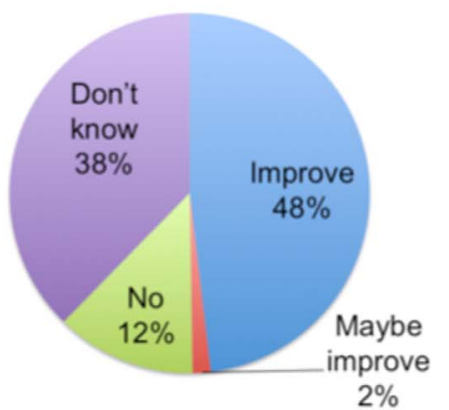

e
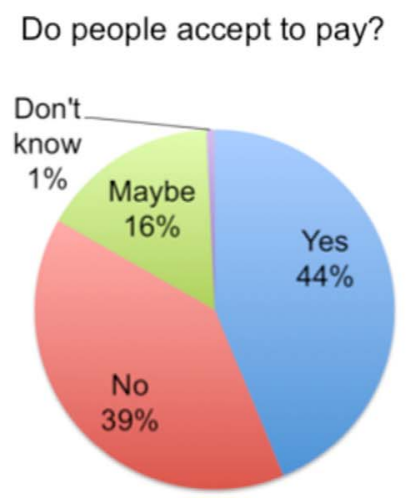

C

Importance of ES

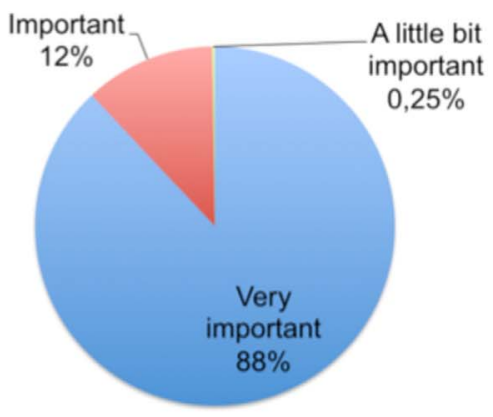

f

How much?

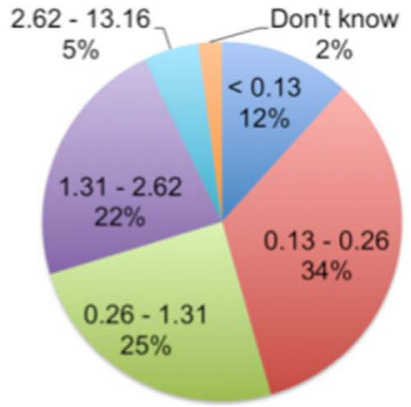

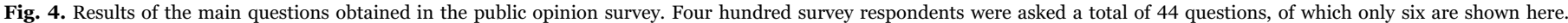
Values in panel $\mathrm{f}$ are in USD\$.

administration of the PES-RC should be done by a city government agency (the city autonomous department for water supply). which would act as an intermediary in the scheme. The PES conjunctural plan elaborated after the 2nd workshop also had considerable influence of local decision makers in the sense that there was a concomitant proposition of a law bid reviewing "director plan", the main law which regulates land use at the municipality level.

\subsection{Public opinion survey}

The main results of the public opinion survey are presented in Fig. 4. $91 \%$ of the population claims that their lives are affected somehow by the loss of natural vegetation in the region. Only $0.5 \%$ of respondents are indifferent to the general importance of natural vegetation remnants (Fig. 4a). 95\% think that the preservation and restoration of native vegetation could improve their life quality (Fig. $4 \mathrm{~b}$ ). On average $88 \%$ of interviewees consider ES as very important (Fig. 4c).

About the correlation between natural vegetation and ES, only $20 \%$ answered that they know the definition of ES, and 43\% of respondents admitted a lack of knowledge if asked about ES, especially when the term "ecosystem services" was used. After a brief explanation, we presented a list of potential ES and requested participants to score each of them from zero to ten to address their importance. Most people ranked agricultural productivity highest (9.3), followed by soil quality (9.2) water conservation (9.2), and by conservation of biodiversity (9.2), climate regulation (8.9) and rural tourism (7.6).

People also agreed that farmers should receive funds to conserve or restore natural vegetation (Fig. 4d), because society as a whole would benefit. In the interviewees' opinions, all governmental instances ought to finance PES (69.5\%). However, when we asked if they were willing to contribute financially to a PES scheme, the majority of interviewed answered they "agree" (44\%) or "maybe" (16\%) to support it (Fig. 4e). About 39\% answered that they would "not agree" to contribute. Those who agreed were asked how much they were willing to contribute, with possible answers ranging from USD \$ 0.13 to > USD \$ 13.15 per month (Fig. 4f; questions were posed in Brazilian Reais [BRL\$], but are converted to 2014 US\$ dollars; BRL\$3.80/dollar). The results according to the social vulnerability index were: Groups $2-5$ were willing to pay a monthly fee of USD $\$ 0.13-0.26$ and Group 1 was willing to pay the highest value of US\$ 13.15 per month, resulting in a median value of USD \$ 0.26 per month (considering that the original question in BRL $\$$ had fixed value classes, it is more meaningful to show here the median rather than the mean preferred value - see questionnaire in Supplementary material).

\subsection{Comparison with PES in Latin America}

The comparison between the main characteristics of PES-RC and the successful cases of PES-LA is summarized in Table 2. Most of the opinions (especially farmers' and decision makers') collected for PES$\mathrm{RC}$ point out water resources as the preferred ES. This characteristic is in agreement with most of the successful cases of PES-LA. The same can be said for the spatial scale, as PES-RC can be considered a local scheme and the success cases of PES-LA are also developed at regional and local scales. Nevertheless, there is a disagreement related to the form of payment: in-kind transactions prevail in PES-LA, while the majority of ES providers (farmers), intermediaries (decision makers) and ES beneficiaries prefer cash transfers in PES-RC. This partial 
Table 2

Comparison between the main characteristics of PES schemes in Latin America (as reviewed by Grima et al. (2016)) and the PES scheme being planned in Rio Claro - SP municipality, Brazil. Only the prevailing characteristic among the successful cases is shown for each category (Grima et al., 2016: Fig. 2).

\begin{tabular}{lll}
\hline & successful PES-LA & PES-RC \\
\hline ES under trade & Water & Water \\
$\begin{array}{l}\text { Scale } \\
\text { Main transaction type }\end{array}$ & Regional/Local & Local \\
$\begin{array}{l}\text { Actors involved } \\
\text { Providers }\end{array}$ & In-kind \& in-kind+cash & Cash \\
$\begin{array}{l}\text { Buyers (beneficiaries) } \\
\text { Intermediaries }\end{array}$ & Private & Private \\
& Private & Public, private \\
\hline
\end{tabular}

a Although "public" and "public+private" alternatives had a nearly as good successrate as the "private" option.

disagreement may be related to the involvement of different actors in RC and LA PES schemes: ES providers are private entities both in PESRC and PES-LA, but ES buyers/beneficiaries are mostly private entities in PES-LA whereas in PES-RC they consist of a mixture of public and private entities (considering that a collective of individuals are envisaged to be the beneficiaries in $\mathrm{RC}$, and that the payer of these $\mathrm{ES}$ will be a public entity). Furthermore, no intermediaries were involved in PES-LA, but are strongly preferred by the stakeholders in PES-RC. Summing up, the characteristics of the PES scheme being planned in Rio Claro matches basically half of the prevailing features of the successful cases in LA.

\section{Discussion}

Our results show that the characteristics of the PES scheme being planned in Rio Claro partly diverge from the bulk of successful cases of PES-LA. This finding raised the question whether priority should be given to the opinions and perceptions of local of stakeholders and their participation for planning the new PES scheme, or whether one should opt to follow the success-characteristics of existing PES-LA. To tackle this question, we present an in-depth discussion of the comparison between PES-RC and PES-LA, considering not only the particularities of the PES-RC, but drawing conclusions for the wider Brazilian and Latin American context.

\subsection{Type of ES traded}

The decision for a PES scheme focusing on water-related services is based on the relevance of maintaining and/or improving water quality and quantity, which are issues easily understood and accepted by ES beneficiaries and providers at the local scale. Furthermore, PES-RC would benefit from probably the most developed and well-implemented water management committee in the country, the existence of which is closely linked to the local/regional institutional preferences for PES schemes based on water resources. Alternative PES schemes based on other ES such as carbon stocks, may lack the direct understanding and acceptance, because the benefits are diluted over time and among the global population, except the transactions received by the ES providers.

Our mapping of different ES reported to be used in RC and their relation to land use (Fig. 3, Table 1) just confirms what is nearly common sense: any action for the maintenance and improvement of regulating services, such as those related to water resources, demands the conservation or restoration of nature habitats - in our case forests, where also the largest number of ES were found to be used. This finding implies that an ES bundle (led by water-related services) (Queiroz et al., 2015) could be linked to the conservation/restoration of these forests. Both the authors of this paper and decision-makers argue that the envisaged PES-RC would be more effective if based on the conservation/restoration of the areas with natural vegetation required by the FC (LR and APP), instead of being based on a single ES or on entire farms. One of the reasons is that in the latter case the verification of adherence to the PES scheme is foreseen to be much more difficult than in the case of tying it to forest-related ES.

Such a PES scheme based on forest conservation/restoration simultaneously aims at the protection of water resources via reducing runoff and increasing water quality. The added value for society is achieved via the protection of forest, benefits hardly attained without such a scheme. Additional benefits are expected for the farmers via synergetic effects of ES, complementing a sustainability-oriented land management, which can positively affect the provision of multiple ES (Mitchell et al., 2014). Several ES-synergies relevant for the study region have been reported. They include farmers benefiting from the presence of native vegetation e.g. in terms of reduced crop damages from pests via an improved control by bats and birds (Maine and Boyles, 2015; Railsback and Johnson, 2014), by improved pollination, increasing the production of local crops (Patrício-Roberto and Campos, 2014), as well as increased opportunities for (eco-) tourism (Tallis et al., 2008) and others. Thus, the protection/restoration of forests would reflect the interests of citizens as stated in the public opinion survey, as well as the objectives of local and regional decision makers to promote and increase water-related ES.

\subsection{Spatial scale}

Developing a new PES scheme at local/regional scales has been more successful than at the federal state or national level (Grima et al., 2016). That information is relevant for regions/locations which do not count on pre-existing PES schemes, as it is the case in our study region and probably many other locations in Latin America. Even at local scale it is a difficult task to define the spatial domain of a PES scheme (e.g. the entire area or part of a municipality). This task may become easier if a PES scheme is directed towards water-related services - so priority can be simply put on areas that are critical for conserving or improving water supply (other services such as biodiversity conservation can make this task more difficult). For PES-RC stated preferences and unofficial "comments" indicate that the scheme will probably start in the section of the municipality that hosts the majority of the catchments and water wells which serve the town. This line of thinking is in agreement with first having respected the preferences of PES-RC stakeholders and second the spatial scales at which successful cases of PES-LA are operating.

\subsection{Transaction type}

The transaction type most mentioned by farmers and decisionmakers in our surveys was the cash transfer based on the OC of the main agricultural crop for the restoration or maintenance of natural vegetation remnants (Seroa da Motta, 1997). A few landowners suggested other economic mechanisms, such as a deduction of farm taxes or the lending of machinery. Their statements reflect the fact that farmers acknowledge the importance of the maintenance (and restoration) of ES, but simultaneously are interested in attractive economic incentives to alleviate barriers to protection/conservation (Wunder and Wertz-Kanounnikoff, 2009).

In PES-LA, the use of "in-kind" compensation tends to reduce the chances of failure, while in the analyzed cases benefits were provided to ES sellers through technical assistance, improvements in access roads, infrastructure works outside and within farm boundaries (such as wells or pipelines for water collection or fencing) or the provision of technical information and training courses for farmers (Grima et al., 2016). When trying to grasp whether stakeholders' preference for cash transactions or successful experiences with in-kind transaction-based PES should be given preference, we are considering the following factors: 
- Rio Claro is part of a region of high agricultural suitability, where land has a high OC (2015 USD\$ 275/ha/year for sugarcane cropping). For any long term commitment, the price of land (which is also high in the national context) should also be considered. Thus, farmers may not feel properly paid/compensated through in-kind transactions following the approaches mentioned above.

- While in-kind transactions may reduce the probability of corruption within a PES scheme, it may not be as attractive and not promote the same level of adherence as cash payments, according to stakeholders.

- Costs for forest restoration (which will also be a focus of PES-RC) are high in our study region. 2015-US\$ 2000/ha have to be considered over a period of three years (Preiskorn and Couto, 2009), amounts which will most certainly not be provided by public buyers. In this case payments could be passed directly to the company responsible for forest restoration complementing farmers' incurred costs.

Beyond the most expensive alternative of $100 \%$ OC compensation, any other level such as $10 \%, 25 \%$ or $50 \%$ of this amount is also plausible, considering that without any PES-like scheme, farmers currently do not receive any assistance for conserving and restoring their forests as required by the FC. It remains to be determined though whether these costs could be justified with correspondingly high benefits (which will be investigated subsequently within this project). The estimated multi-billion losses (Martins, 2015) caused by the recent severe four-year drought in Southeast Brazil, are a clear example of how potentially high costs of a PES scheme can be justified by correspondingly much higher benefits or avoided losses. In this example financial losses have at least partly been caused by the lack of forest vegetation in headwaters and alongside water bodies, which has negatively affected water availability in large cities in Southeast Brazil - namely in São Paulo metropolitan area. Thus, for PES-RC we need to explore, whether the potentially high costs caused by the preferred cash transactions can be justified with expected benefits or avoided losses for the economy or the citizens of the municipality. Magrin et al. (2014) report one strong cause of failure of PES in Guatemala and Ecuador as the uniformity of cash payments, regardless of the environmental gains brought about by individual farmers. In this sense the initial planning that took shape in PES-RC is, at the one hand, at the good side given the revealed preference for payments based on protected area of land, but, on the other hand, shall be a matter of concern for PES-RC given the aforementioned disagreement among stakeholders about level of payments for farmers to simply conserve existing forests and farmers who need to restore their forests.

\subsection{Actors involved}

The Coase theorem states that the participation of private entities should be given preference for the reduction of environmental contends and externalities (Schomers and Matzdorf, 2013). Regarding the identity of ES sellers - for which there is agreement between PES-RC and PES-LA - it hardly could be different, given the few existing rural public properties in our study area, all of which are protected areas with a good level of conservation and maintenance of ES.

There was a consensus among all stakeholders in PES-RC that the local government should organize and administer any future program that may take place. Thus, public institutions are the "natural" buyers of ES, considering that regulating services serve diffuse beneficiaries, and therefore are of collective interest. It should be noted however that although having private ES buyers is more common in PES-LA, there is also a considerable number of cases in which the buyers are public (Grima et al., 2016: Fig. 1).

For intermediaries, we also found that the disagreement between PES-RC (with) and PES-LA (without) is partly due to a lack of trust between sellers and buyers in RC (probably caused by the lack of recognition and of interest of urban population on rural issues, given its low economic importance locally), but also strongly due to the low level of organization of the ES providers/sellers - i.e. farmers - which could otherwise cope with the management of transactions directly with ES beneficiaries/buyers. Therefore although the involvement of intermediaries (either with a governmental body or an NGO) may impair success and trust elsewhere, in PES-RC it may be needed, given that neither buyers nor sellers have the capacity for managing a PES scheme.

\subsection{Stakeholder participation}

The strong focus on stakeholder participation in PES-RC ensures that interests and perspectives of different groups and local demands are considered, facilitating consensual approaches (Wegner, 2016). The strategy is comparable to procedures suggested for participatory scenario development (Alcamo et al., 2005; Henrichs et al., 2010; Priess and Hauck, 2014) increasing the visibility and legitimacy of the policy process, ultimately boosting the chance of success of environmental public policies. This line of thought considers environmental policies much more as a political process (with the involvement of multiple stakeholders, discourses and interests) rather than a technical/science communication problem (Cáceres et al., 2016). We interpret that the latter would be the case if one simply would try to implement PES-RC based on known success-factors, ignoring the specific agendas and preferences of stakeholders - which is the case, for example in the study by Banks-Leite et al. (2014) [see also Lapola et al., 2014]. In fact the PES scheme proposed by Banks-Leite et al. (2014) provides a clear example of a technocratic approach upon the governance of common resources, and why any PES scheme should be closely linked with existing public policies to avoid unintended effects. As such, PES development processes in Rio Claro and elsewhere need to be as participatory and inclusive as possible to increase the chances of success (Turner et al., 2016). On the other hand, there are many examples of successful PES that did not follow a participatory approach during their planning phase [e.g. Pagiola et al. (2012) in the Atlantic Forest; Corbera et al. (2007) in Central America].

Ultimately, too little empirical understanding exists about the diversity of stakeholders, their motivations and preferences for various $\mathrm{ES}$, and little evidence about the potential social conflicts and inequities arising from access to specific ES by different individuals and groups. Without this knowledge, even if we understood how social and ecological systems interact to produce ES, we would not understand how varying ES provision affects the well-being of different stakeholder groups to produce PES-like public policies (Bennett et al., 2015; Turner et al., 2016).

\section{Conclusions: road to success through inclusiveness or "copy and paste"?}

This study used a variety of methods to assess and evaluate the main characteristics of the PES scheme currently being developed in Rio Claro. The characteristics were systematically confronted with the features of successful PES-LA. The comparison reveals a partial agreement, a finding which takes us back to the key question we phrased at the beginning of the discussion whether local factors such as the preferences of stakeholders or the known success-factors (and even failure causes) of current PES-LA should be the first design priority. There are reasonable arguments for both approaches, as presented above. Nevertheless we argue - just as recent literature on the subject also shows (e.g. Bennett et al., 2015; Cáceres et al., 2016) - that respecting the opinions of stakeholders increases the legitimacy, adherence and chances of success of PES-like public policies, despite the risks incurred in not following success-cases. Based on the successful participatory process in Rio Claro and recent experiences of miss-specified PES-schemes lacking an inclusive approach (Magrin 
et al., 2014), we suggest participatory strategies as an additional success criterion. Consequently, the answer to our initial question is that we clearly favor a pathway learning from similar successful cases, but strongly building on stakeholder inclusion and other local factors rather than promoting a "copy and paste" of success stories.

\section{Outlook: implementation steps}

Based on our results and additional external inputs and considerations, the first very concrete steps towards operationalization of the PES-RC scheme are being undertaken by the government of Rio Claro municipality. The city council is expected to vote for the creation of the PES scheme into the Town's Land Use Plan law bill in a few months. The bill establishes priority areas of APP, LR and forest remnants, mostly aiming at maintenance and improvement of water flows and water quality. It also envisages a period of two years to establish the rules and other crucial regulations, such as to identify ES providers, and define the most appropriate and accepted method for a monetary valuation of ES. Thus, the current period is crucial to provide arguments to decide which characteristic PES-RC shall be based on something that will be explored objectively in a 3rd project workshop. The authors plan to address this and other challenges (e.g. the environmental benefits brought about by the PES-RC scheme) in a similar participatory and transparent fashion, considered to be essential for the final implementation of the new PES in Rio Claro.

\section{Acknowledgements}

This study is funded by the EU FP7 project OpenNESS Operationalization of Natural Capital and Ecosystem Services [Grant no. 308428], as contribution of the Brazilian case study - BIOB \#26 (DML, PFP, JAP), by Coordenação de Aperfeiçoamento de Pessoal de Nível Superior/Ciência Sem Fronteiras [Grant no. 88881.030372/ 2013-01] (RAS, GBP, DML, JAP), and Fundação de Amparo à Pesquisa do Estado de São Paulo - FAPESP [Grant no. 2014/083450] (MCT). We are grateful to all the stakeholders who kindly shared their time to take part in this project and also to J.P. Darela-Filho, M. M. Roberto and M. S. Morinaga for support with GIS data and figures.

\section{Appendix A. Supplementary material}

Supplementary data associated with this article can be found in the online version at doi:10.1016/j.ecoser.2016.09.013.

\section{References}

Alcamo, J., van Vuuren, D., Ringler, C., Cramer, W., Masui, T., Alder, J., Schulze, K., 2005. Changes in nature's balance sheet: model-based estimates of future worldwide ecosystem services. Ecol. Soc. 10, 19

Banks-Leite, C., Pardini, R., Tambosi, L.R., et al., 2014. Using ecological thresholds to evaluate the costs and benefits of set-asides in a biodiversity hotspot. Science 345, 1041-1045. http://dx.doi.org/10.1126/science.1255768.

Bennett, E.M., Cramer, W., Begossi, A., et al., 2015. Linking biodiversity, ecosystem services, and human well-being: three challenges for designing research for sustainability. Curr. Opin. Environ. Sustain. 14, 76-85. http://dx.doi.org/10.1016/ j.cosust.2015.03.007.

Brasil, 2012. Federal Law 12.651 25/May/2012. Dispõe sobre a proteção da vegetação nativa. Presidência da República, Brasília. Available at: 〈http://www.planalto.gov. br/ccivil_03/_ato2011-2014/2012/lei/112651.htm〉

Cáceres, D.M., Silvetti, F., Díaz, S., 2016. The rocky path from policy-relevant science to policy implementation-a case study from the South American Chaco. Curr. Opin. Environ. Sustain. 19, 57-66. http://dx.doi.org/10.1016/j.cosust.2015.12.003.

Cassola, R., 2010. TEEB case: Payments and Technical Support for Reforestation and Soil Conservation for Watershed Protection. TEEB, Brazil

Cochran, W.G., 1997. Sampling Techniques. John Willey \& Sons, New York.

Corbera, E., Kosoy, N., Martinez-Tuna, M., 2007. Equity implications of marketing ecosystem services in protected areas and rural communities: case studies from Meso-America. Glob. Environ. Change 17, 365-380.

Crossman, N.D., Burkhard, B., Nedkov, S., et al., 2013. A blueprint for mapping and modelling ecosystem services. Ecosyst. Serv. 4, 4-14. http://dx.doi.org/10.1016/ j.ecoser.2013.02.001.
Grima, N., Singh, S.J., Smetschka, B., Ringhofer, L., 2016. Payment for Ecosystem Services (PES) in Latin America: analysing the performance of 40 case studies. Ecosyst. Serv. 17, 24-32. http://dx.doi.org/10.1016/j.ecoser.2015.11.010.

Haines-Young, R.Potschin, M., 2013. Common International Classification of Ecosystem Services (CICES): Consultation on Version 4, August-December 2012. Nottingham.

Henrichs, T., Zurek, M., Eickhout, B., Kok, K., Raudsepp-Hearne, C., Ribeiro, T., van Vuuren, D., Volkery, A., 2010. Scenario development and analysis for forwardlooking ecosystem assessments. In: Ash, N., Blanco, H., Brown, C. (Eds.), Ecosystems and Human Well-Being: A Manual for Assessment Practitioners. Island Press, Washington, 151-220. http://dx.doi.org/10.1126/science.1196624.

IBGE, I.B. de G.E., 2014. Sistema IBGE de Recuperação Automática - SIDRA. 〈http:// www.sidra.ibge.gov.br/bda/agric/default.asp? z=t \& o=11 \& i=P $>$ (accessed 07.06. 15)

Lapola, D.M.Soares-Filho, B.S.Ribeiro, M.C.Pinho, P.F.Patricio, G.B.Silva, R.A.Teixeira, M.C.Ribeiro, J.W.Priess, J.A., 2014. Using ecological thresholds to evaluate the costs and benefits of set-asides in a biodiversity hotspot | Science Comments. 〈http:// comments.sciencemag.org/content/10.1126/science.1255768> (accessed 12.11.15).

Lapola, D.M., Martinelli, L.A., Peres, C.A., et al., 2014. Pervasive transition of the Brazilian land-use system. Nat. Clim. Change 4, 27-35. http://dx.doi.org/10.1038/ nclimate2056.

Maes, J., Teller, A., Erhard, M., et al., 2013. Mapping and Assessment of Ecosystems and their Services. An analytical framework for ecosystem assessments under action 5 of the EU biodiversity strategy to 2020. http://dx.doi.org/10.2779/75203.

Magrin, G., Marengo, J., Boulanger, J.P., Buckeridge, M.S., Castellanos, E., Poveda, G., Scarano, F.R., Vicuña, S., 2014. Central and South America. In: Climate Change 2014: Impacts, Adaptation and Vulnerability. Contribution of Working Group II to the Fifth Assessment Report of the Intergovernmental Panel on Climate Change. Cambridge University Press, Cambridge, United Kingdom and New York, NY, USA. pp. 1499-1566.

Maine, J.J., Boyles, J.G., 2015. Bats initiate vital agroecological interactions in corn. PNAS 112, 12438-12443. http://dx.doi.org/10.1073/pnas.1505413112.

Martins, R., 2015. A seca já começou a afetar a economia. Cart. Cap. 〈http://www. cartacapital.com.br/revista/835/a-seca-da-economia-4105.html (accessed 12.11. 15).

Mitchell, M.G.E., Bennett, E.M., Gonzalez, A., 2014. Forest fragments modulate the provision of multiple ecosystem services. J. Appl. Ecol. 51, 909-918. http:// dx.doi.org/10.1111/1365-2664.12241.

Pagiola, S., Carrascosa Von Glehn, H., Taffarello, D., 2012. Experiências de Pagamentos por Serviços Ambientais no Brasil. SMA/CBRN, São Paulo.

Patrício-Roberto, G., Campos, M., 2014. Aspects of landscape and pollinators-What is important to bee conservation? Diversity 6, 158-175. http://dx.doi.org/10.3390/ d6010158.

Peterson, R.A., Merunka, D.R., 2014. Convenience samples of college students and research reproducibility. J. Bus. Res. 67, 1035-1041. http://dx.doi.org/10.1016/ j.jbusres.2013.08.010.

Phalan, B., Onial, M., Balmford, A., Green, R.E., 2011. Reconciling food production and biodiversity conservation: land sharing and land sparing compared. Science 333, 1289-1291. http://dx.doi.org/10.1126/science.1208742.

Preiskorn, G.M., Couto, H.T.Z., 2009. Quantificação e monitoramento de biomassa e carbono em plantios de áreas restauradas. In: Rodrigues, R.R., Brancalion, P.H.S., Isernhagen, I. (Eds.), Pacto Pela Restauração Da Mata Atlântica: Referencial Dos Conceitos E Ações de Restauração Florestal. Instituto BioAtlântica, São Paulo, $147-157$.

Priess, J.A., Elger, R., Hauck, J., 2014. The ESM-App - a new smartphone application to map ecosystem services. In: Ames, D.P., Quinn, N.W.T., Rizzoli, A.E. (Eds.). Proceedings of the International Environmental Modelling and Software Society (iEMSs) 7th Intl. Congress on Env. 2014 Modelling and Software. San Diego.

Priess, J.A., Hauck, J., 2014. Integrative scenario development. Ecol. Soc. 19, 12. http:// dx.doi.org/10.5751/ES-06168-190112.

Queiroz, C., Meacham, M., Richter, K., Norström, A.V., Andersson, E., Norberg, J., Peterson, G., 2015. Mapping bundles of ecosystem services reveals distinct types of multifunctionality within a Swedish landscape. Ambio 44, 89-101. http:// dx.doi.org/10.1007/s13280-014-0601-0.

Railsback, S.F., Johnson, M.D., 2014. Effects of land use on bird populations and pest control services on coffee farms. Proc. Natl. Acad. Sci. 111, 6109-6114. http:// dx.doi.org/10.1073/pnas.1320957111.

Rio Claro, P.M., 2014. Diagnóstico ambiental e desenvolvimento de sistemas de implementações de projetos de recuperação da qualidade dos corpos d'água. Rio Claro.

Ritchie, J., et al., 2014. Designing and selecting samples. In: Ritchie, J. et al. Qualitative Research Pratice. A Guide for Social Science Students \& Researchers. 2nd Ed. SAGE, Los Angeles, London, New Delhi, Singapore, Washington DC.

Schomers, S., Matzdorf, B., 2013. Payments for ecosystem services: a review and comparison of developing and industrialized countries. Ecosyst. Serv. 6, 16-30. http://dx.doi.org/10.1016/j.ecoser.2013.01.002.

Seroa da Motta, R., 1997. Manual para Valoração Econômica de Recursos Ambientais. IPEA/MMA/PNUD/CNPq, Rio de Janeiro.

Soares-Filho, B., Rajão, R., Macedo, M., Carneiro, A., Costa, W., Coe, M., Rodrigues, H., Alencar, A., 2014. Cracking Brazil's forest code. Science 344, 363-364. http:// dx.doi.org/10.1126/science.1246663.

Tallis, H., Kareiva, P., Marvier, M., Chang, A., 2008. An ecosystem services framework to support both practical conservation and economic development. Proc. Natl. Acad. Sci. USA 105, 9457-9464.

Turner, B.L., II, Esler, K.J., Bridgewater, P., et al., 2016. Socio-Environmental Systems (SES) research: what have we learned and how can we use this information in future research programs. Curr. Opin. Environ. Sustain. 19, 160-168. http://dx.doi.org/ 
10.1016/j.cosust.2016.04.001.

Vedovato, L.B., 2013. Áreas prioritárias para conservação e restauração da paisagem utilizando multi-caminhos e informações de avifauna. Universidade Estadual Paulista.

Wegner, G.I., 2016. Payments for ecosystem services (PES): a flexible, participatory, and integrated approach for improved conservation and equity outcomes. Environ. Dev. Sustain. 18, 617-644.

Wunder, S., Wertz-Kanounnikoff, S., 2009. Payments for ecosystem services: a new way of conserving biodiversity in forests. J. Sustain. For. 28, 576-596. http://dx.doi.org/ $10.1080 / 10549810902905669$. 